HRRI Working Paper 09-02

Industrial Relations Center

University of Minnesota

\title{
Reciprocity in a Two-Part Dictator Game
}

by

\begin{abstract}
Avner Ben-Ner, Industrial Relations Center, University of Minnesota and
Louis Putterman, Department of Economics, Brown University

with Fanmin Kong, Guanghua School of Management, Peking University

and Dan Magan, Industrial Relations Center, University of Minnesota
\end{abstract}

March 2002

Abstract. We conduct a dictator game experiment in which recipients in an initial game become dictators in a second game. When the subjects paired remain the same, the amount sent back is strongly correlated with the amount received, despite the fact that the interaction is anonymous and is known to be one-time and zero-sum in nature. When the initial recipient is instead paired with a third subject, a less significant and lower-valued correlation between amounts received and sent is exhibited. Intelligence and personality test results, gender, and other characteristics also help to predict sending behavior and degree of reciprocity. (JEL: C78, C91, D64) (Keywords: reciprocity, dictator game, cognition, personality, altruism.) 


\section{Reciprocity in a Two-Part Dictator Game*}

\section{Introduction}

The assumption of self-interest has played a major role in powering the progress of economics. But evidence arguing for a more nuanced model of preferences has been growing and has received respectful treatment by an increasing number of economists in recent years. A large experimental literature on games of endowment division, including the dictator and ultimatum games, suggests that many agents do not act in accordance with the postulates of strict self-interest and rationality. In the dictator game, those postulates imply that the divider of an endowment will give nothing to her potential beneficiary. In the ultimatum game, they imply that the divider will give only enough namely, the smallest portion into which the endowment can be divided - to make it worthwhile for the recipient not to reject the deal. ${ }^{1}$ In neither case is the implication well supported. $^{2}$

Even more dramatic, perhaps, is evidence that at least some people evince reciprocity in their interactions with others, and that many people appear to anticipate such reciprocity. Fehr, Gächter, and Kirschsteiger (1997) implemented an experimental design in which some subjects, dubbed "employers," offered to enter into wage-andeffort agreements with other subjects, dubbed "employees," where both wages and effort

\footnotetext{
* An earlier version of this paper was presented at the American Economics Association panel on Economics, Values and Organization, Allied Social Sciences Association meetings, Chicago, January 1998, and at various departmental seminars. We would like to express our appreciation to John Dickhaut for his help in designing the experiment, to discussants and seminar participants, and to several anonymous referees for their valuable suggestions.

1 While it has been demonstrated that sending by dividers is roughly consistent with payoff-maximization given observed rejection rates, the same cannot be said for rejections, which indicate that those in the receiving position, at least, often act as if maximizing payoffs were not their only goal.

${ }^{2}$ Summaries are provided by Camerer and Thaler (1995), and Fehr and Schmidt (2000).
} 
represented transfers of experimental endowment funds from one subject to the other.

The design was such that employers were forced to pay the wage offered, but employees could "shirk" by providing less than the promised amount of "effort." The experimental results show that many "employees" reciprocated high wages with high effort despite the unenforceability of their contracts. Similarly, McCabe, Rassenti, and Smith (1996) found that many experimental subjects reject a Nash equilibrium with positive payment attainable by a sequence of self-interested moves in favor of a Pareto-dominating cooperative equilibrium attainable only when the first mover trusts the second mover to respond to his or her riskier (or "trusting") choice with a "reciprocally fair" rather than an "opportunistic" move. Consistent with reciprocity theory, the trust of such subjects was more often than not validated by second-movers' actions. ${ }^{3}$

Some economists, including Fehr and Schmidt (2000) and Bolton and Ockenfels (2000), have proposed models of agents' utility functions that incorporate concerns over fairness or relative outcomes consistent with the above-mentioned experimental results. Others, such as Rabin (1993), suggest that beliefs about intentionality may be as important as are relative outcomes in driving fairness-related behaviors. ${ }^{4}$ Still others follow the pioneering work of Schelling (1960), Hirshleifer (1987) and Frank (1988) who suggest a role for the emotions in assuring that agreements are enforced. Emotional

${ }^{3}$ Both Fehr et al.(1997) and McCabe et al. (1996) separately test the effect of allowing subjects to "punish" partners who cheat on an implicit offer of cooperation. In these experiments, punishing is a dominated strategy since it is costly and brings no direct benefit to the punisher. Investment in a reputation for having moralistic or punitive tastes cannot explain the behavior in treatments in which the same subjects are never re-matched. Yet, many subjects are observed to punish cheaters, and the introduction of the opportunity to punish appears in itself to deter cheating, implying that the potential cheaters also operate with a model of human nature that incorporates an inclination to punish that is lacking in the standard neoclassical model.

${ }^{4}$ Falk and Fischbacher (1998) incorporate intentionality into a model that in other respects resembles those of Fehr and Schmidt (2000) and of Bolton and Ockenfels (2000). 
mechanisms are emphasized, for instance, by Hoffman, McCabe, and Smith (1998), who suggest that their reciprocity findings accord with the approach of the new field of evolutionary psychology. Proponents of that field, notably Cosmides and Tooby (1993), see behavioral propensities including reciprocity and the punishment of cheaters, as "hard-wired" into human nature by natural selection. ${ }^{5}$

This paper reports the results of an experiment that uses a simple design to obtain evidence about (a) the strength and pervasiveness of the impulse towards reciprocity, and (b) the roles of experience, intelligence, and personality in influencing its expression. Unlike Fehr et al. (1997) and McCabe et al. (1996), we study a setting in which not only is investment in reputation ruled out, but even the possibility of mutual benefit as a result of reciprocal exchange is absent as a motive for reciprocity. The design is a two-part dictator game in which the first stage is conventional (dictators are unaware of the twopart structure) and recipients in the first stage become dictators in the second one. Because both stages are straightforward games of division and the amount to be earned by the subjects in the aggregate is unaffected by their decisions, the game played is strictly zero-sum. If subjects evince reciprocity in this setting, then we have additional and qualitatively different evidence that a propensity towards reciprocity is deeply imbedded in the preference structures of actors. Complementary evidence gathered from questionnaires also permits us to investigate whether any reciprocity that is exhibited is a function of factors in individuals' past social environments, of their intelligence, and of their personality traits. We find that agents who have been "done a good turn" tend to be more generous to those who have treated them in this way, but that the amount sent is

\footnotetext{
${ }^{5}$ Recently, Fehr and Gächter (2002) also propose an emotion based, evolutionary interpretation.
} 
largely unaffected by the amount received when second-round dictators are matched randomly with new partners.

The rest of the paper proceeds as follows. In section 1, we sketch a paradigm of human preference formation that is consistent with the existing reciprocity findings, and that offers a starting point for our analysis. Section 2 describes the experiment, while section 3 presents our results and analysis. Section 4 summarizes our findings and presents concluding remarks.

\section{Reciprocity and The Co-Evolutionary Preference Paradigm}

Standard economics holds that individuals act so as to maximize utility, represented as a positive function of income, consumption, or wealth, and of leisure. It does not ask why this is so. A possible explanation is that in the course of human evolution, individuals who were genetically inclined to maximize these objectives with appropriate weights turned out to be better adapted to their environments than were those who were not so inclined. This seems plausible at first blush because all animals must wrest resources from their environments for survival, and because doing this with less rather than more exertion saves on the quantity of resources required. The evolutionary theory used by biologists, however, holds that nature will have selected out those genetically transmitted traits that maximize the number of surviving bearers of a set of

genes. The genes that survive are those that random mutation programmed to act "as if" solving the problem of successful proliferation, not survival of the individual organism per se. 
Through most of their evolution, human beings lived in small groups in which reasonably cooperative social relations and a certain degree of reciprocity and sharing were requisites of survival. Banding played a crucial role in defense against predators and members of unrelated bands. Sharing is hypothesized to have been critical in that a given hunter faced uncertainty about whether he would return with game from any particular hunt, and all members of the group could potentially benefit when a given hunt's spoils were divided among both the successful and the unsuccessful. ${ }^{6}$

In Ben-Ner and Putterman (1998), we argue for a dual approach to the evolution of human preferences - dual because both genes and experience (social and other) play important roles. ${ }^{7}$ While genetic material lays down predispositions, experience shapes the genotype into an actual behaving organism or phenotype. Thus, genetic predispositions may render human beings receptive to socially transmitted norms of reciprocal fairness, and they may be born with the biochemical machinery that triggers anger and desires for revenge in the event of being taken advantage of. However, the contexts in which reciprocity and revenge are called forth, and the levels of reciprocal or vengeful behavior elicited, will vary according to evolved (and evolving) cultural norms (Boyd and Richerson, 1985).

Individuals are also likely to differ in the details of genetic endowment (a person may be more or less prone by temperament to anger, moral socialization, etc.), and

\footnotetext{
${ }^{6}$ Note the role of diminishing marginal utility: we each get higher average payoffs from sharing, because the extra payoff from keeping the meat to myself when I succeed is low relative to the benefit from sharing some of your meat when I do not, and vice versa. See Cosmides and Tooby (1993), and for a relevant discussion of sharing and food gathering in primitive societies, Kaplan and Hill (1985). See also the discussion of reciprocity by Hoffman et al. (1996), and especially Hoffman et al. (1998).
} 
members of the same society are exposed to different environmental influences.

Environmental influences on the habit of reciprocity may include, for instance, religious training and the social modeling of parents. Aspects of personality that may reflect both genetic and environmental influences could also influence reciprocity.

Cognitive capability, too, might affect reciprocity by determining the degree to which individuals discriminate between situations in which reciprocity is potentially beneficial and those in which there are gains to be had from behaving more opportunistically. A more intelligent individual might overrule her built-in inclination to reciprocate kindness when it is clear to her, but perhaps less clear to a less intelligent counterpart, that there can be no gain to her or to her family. A possible test of the argument that reciprocity is displayed in one-shot games as a carry-over from more familiar repeated-game environments is to examine whether reciprocity is negatively correlated with intelligence.

So far, we have addressed only reciprocity between specific individuals. Reciprocity may be said to be specific when, following A's favorable action towards B, B acts favorably towards A. One might raise the somewhat different question of whether favorable acts by A towards B will increase B's tendency to act similarly towards C, either through some sort of modeling effect or by inducing a sense of obligation. ${ }^{8} \mathrm{We}$ might call such a diffusing of favorable actions within a population generalized

\footnotetext{
${ }^{7}$ The role that Amartya Sen (1998) and others accord to conscious moral reflection is also not inconsistent with our approach. Dual evolution models have been presented by Cavalli-Sforza and Feldman (1981), Lumsden and Wilson (1983), Boyd and Richerson (1985), and Durham (1991).

${ }^{8}$ Cox (2000) provides an example in which a driver who has been permitted to enter a congested roadway by a second driver who has the right of way is more likely to perform a similar favor to other drivers once on the road. "If another driver extends me the courtesy of letting me into the street, the probability is
} 
reciprocity, although in a large population in which the initiator may never be on the receiving end of the chain of gifts or favors which she started, it is unclear that the term "reciprocity" should be used at all. ${ }^{9}$ In our experiment and analysis, we allow that there may exist "generalized" as well as "specific" (or "pairwise") reciprocity, and we test whether these phenomena are of similar or equal strength.

Equation (1) provides a simple representation of preferences relevant to an interaction between two agents, $i$ and $j$ :

$$
\mathrm{U}_{\mathrm{i}}=\mathrm{f}\left(\mathrm{y}_{\mathrm{i}}, \alpha\left(\mathrm{y}_{\mathrm{j}}, \mathbf{X}_{\mathrm{i}}, \mathbf{X}_{\mathrm{j}}\right), \rho\left(\mathrm{a}_{\mathrm{i}}, \mathrm{a}_{\mathrm{j}}, \mathbf{X}_{\mathrm{i}}, \mathbf{X}_{\mathrm{j}}, \mathrm{S}\right)\right)
$$

Here, $\mathrm{y}_{\mathrm{i}}$ is $i$ 's income or wealth, $\mathbf{X}_{\mathrm{i}}$ and $\mathbf{X}_{\mathrm{j}}$ are vectors of $i$ 's and $j$ 's personal characteristics, $\mathrm{a}_{\mathrm{i}}$ and $\mathrm{a}_{\mathrm{j}}$ are actions taken by $i$ and $j$, respectively, $\mathrm{S}$ identifies the nature of the situation in which the agents find themselves (determining whether norms of reciprocity are or are not activated), $\alpha$ is a measure of altruism or other-regarding preference, and $\rho$ is a measure of adherence to a norm of reciprocity (called by Ben-Ner and Putterman (1998) a "process-regarding preference"). Here agent $i$ 's utility is increasing in her own income, but also, if $i$ is altruistically inclined towards $j\left(\partial \alpha / \partial \mathrm{y}_{\mathrm{j}}>0\right)$, in the income of $j$. Agent $i$ 's utility may also be increased by taking some actions $\mathrm{a}_{\mathrm{i}}$ rather than others given the action of agent $j$, $\mathrm{a}_{\mathrm{j}}$; for instance, in the case of a preference for reciprocity, actions by $j$ that benefit $i$ cause $\rho$ and accordingly $\mathrm{U}_{\mathrm{i}}$ to be initially increasing in actions by $i$ that benefit $j$. Whether altruism or reciprocity is present, and its

essentially 1 that I will extend the same courtesy to the next driver I encounter on that street," he writes. (We thank a referee for bringing the example to our attention).

${ }^{9}$ The term "indirect reciprocity" is sometimes used with the same meaning. Although Alexander (e.g., 1987) avoids the term "generalized reciprocity" in favor of "indirect reciprocity" because of what he takes to be the misuse of the former by Marshall Sahlins, he also writes (p. 85) "Perhaps both terms will survive: indirect reciprocity for cases in which the return explicitly comes from someone other than the recipient of the original beneficence, and generalized reciprocity for social systems in which indirect reciprocity has become complex and general." Note that our experimental treatment does not permit the kind of 
degree, can depend upon the characteristics of both parties; for instance, an element of the vector of characteristics $\mathbf{X}$ could be ethnicity, and altruism or reciprocity might be elicited from $i$ when $j$ belongs to the same ethnic group, but not otherwise. Also, both altruism and reciprocity may be stronger or weaker depending upon characteristics of person $i$, such as genetically and environmentally determined personality traits, exposure to moral socialization, and intelligence.

\section{The Two-Part Dictator Game Experiments}

In the dictator game, one subject, the dictator or sender, is given a sum of money that he or she is free to divide with another subject, the recipient, as s/he may like. Unlike the ultimatum game, the dictator's choice is final, and need not be agreed to by the recipient. The dominant strategy for a self-interested individual in a one-shot dictator game with an anonymous partner and under conditions of anonymity with respect to the experimenter is to give nothing.

Previous experiments have shown that most dictators give more than nothing to recipients. Such behavior can still be consistent with pure self-interest on the part of dictators under certain circumstances - for instance, that the dictator and recipient know one another and will have future interactions in which the dictator's generosity will be rewarded. The dictator might also be investing in a reputation with the experimenter that could lead to future rewards. Some evidence of deviation from self-interest persists even in double-blind anonymous games where there is assurance of anonymity both among subjects and between subjects and experimenters, although sharing is noticeably lower in

observation by $\mathrm{C}$ of A's generosity toward $\mathrm{B}$ which is required by theories of indirect reciprocity such as that of Nowak and Sigmund (1998). 
most double-blind treatments (see Forsythe et al., 1994, Hoffman et al., 1994, Eckel and Grossman, 1996a, and Bolton et al., 1998).

We carried out a two-part dictator game experiment in which those assigned the role of recipients in the first part of the experiment became in turn dictators in the second part. The first round was fully conventional in the sense that first-round dictators were not informed that a second round would take place, although it included small differences in information to which we refer below. Giving in the first round may thus be thought of as unconditional giving. Second-round dictators were divided into two treatment groups. Roughly half were matched with the same person whose recipient they had been in the first round. The remaining dictators were matched with a different person. All subjects remained anonymous to one another, and dictators and recipients were seated in different rooms. The purpose of the second-round experiment, which is analyzed here in detail, was to determine whether individuals would reciprocate any "generosity" shown by firstround senders, whether their responses would differ under the same partner ("specific reciprocity”) and different partner (“generalized reciprocity”) treatment, and whether their responses could be predicted on the basis of personal history, intelligence, and personality measures.

The experiment was conducted by a team at the University of Minnesota in October 1997. It involved a little over 200 undergraduate students who were recruited without direct contact with the experimenters. The subjects responded to an e-mail invitation to the university's entire freshman class (which numbered about 5,000). The invitations were issued individually (the identities of other recipients were not shown on the invitation), and asked for participation in an economics/psychology experiment that 
would last up to two hours, that would require no physical effort, that would assure subjects' anonymity, and that would earn them a $\$ 15$ participation fee and possibly additional earnings. ${ }^{10}$ A supplementary administration of the first-round portion of the experiment only, following identical procedures, was carried out at Brown University in October 1998. Results from the Brown experiment are pooled with those from Minnesota in one part of our regression analysis to analyze in a comparative fashion the determinants of first-round sending behavior, but we devote no other attention here to that session, which lacked the second round that is central to the present paper.

Over 400 students responded to the invitation at Minnesota, and a little over half of these showed up at the appointed times and locations. These students had spent only about one month at the University (student population roughly 40,000) prior to the experiment, and are unlikely to have known each other or to have participated in other such experiments. Subjects who subsequently learned of their roles as dictators or recipients entered different rooms in separate buildings and were assured explicitly of their anonymity. Once they entered their assigned room, there was no way to connect an individual to an e-mail address or to a name.

In addition to the $\$ 15$ fee for participation, each participant was given $\$ 10$ in 1 dollar bills that he or she was asked to keep or divide with an anonymous recipient. The experiments were fashioned in a manner that closely follows the double-blind design of Hoffman et al. (1996) and Eckel and Grossman (1996a) so as to assure anonymity both

\footnotetext{
${ }^{10}$ The range of earnings in similar experiments was not communicated to the participants so as not to provide any unintended normative yardstick to senders. The relatively high participation fee, which could have some bearing upon the amounts sent, was deemed necessary due to the time required by participants to complete the survey and other forms described below.
} 
among subjects and between subjects and experimenters. ${ }^{11}$ However, the instructions

follow more closely the "divide an endowment" language used by Forsythe et al. (1994)

rather than the "set a price" language used by Hoffman et al. $(1996,1998)$ (see Bolton et

al. 1998 for a discussion of a possible difference in framing effects). All subjects also

completed a questionnaire regarding their personal experiences and characteristics, a

cognitive test (the Wonderlic), ${ }^{12}$ and a personality test (the short version of the NEO

Five-Factor Inventory). ${ }^{13}$ The Appendix (posted on the journal web site) contains the

instructions given to second-round dictators. ${ }^{14,15}$

\begin{abstract}
${ }^{11}$ In particular, after the random selection of two room assistants - we used this term rather than 'monitors' to enhance the sense of anonymity - from among the subjects, each remaining subject was randomly handed an envelope marked on the upper-right corner with an identification number used to associate his/her subsequent sending choice with his/her survey and test results. General instructions were taped to the envelope (see Appendix). Inside were smaller envelopes of different colors containing various instruments (the NEO, Wonderlic, and survey questionnaire, to be described later), as well as a money envelope marked with the same ID number as the external envelope. Each money envelope contained 10 slips of paper and 10 one dollar bills, mixed together - the slips being included so that sending decisions would take the same amount of time to implement, and the resulting envelopes would be of the same thickness, regardless of the amount sent. The decision on how much money and how many slips of paper to retain and to send was made at "privacy stations" fashioned so as to hide the subject from the knee up (thus providing complete privacy for transferring money or paper slips from envelopes to one's own pockets). The small envelope containing the slips of paper and/or money was deposited by the subjects in a box. When all first-round subjects completed their decisions, a room assistant brought the box with small envelopes to counters who waited outside each room. In the presence of the room assistant, the counters registered the number of dollars included in the money envelope and the ID number of the sender. Room assistants and counters transported the money envelopes to the appointed receiving room and gave them to the room assistants for distribution there. After completion of all tasks, subjects deposited the large envelopes containing the NEO, Wonderlic, and survey into a large box, after which first-round subjects received the envelopes sent by second-round dictators and proceeded to the door where the in-room experimenter handed out their participation fee.
\end{abstract}

${ }^{12}$ The Wonderlic Personnel Test is a timed, 50-item cognitive ability measure commonly used in the preemployment selection context. Wonderlic scores are highly consistent with other well-recognized measures such as the Wechlsler Adult Intelligence Scale, the General Aptitude Test Battery, and the Stanford Achievement Test. See, e.g., Hawkins et al. (1990) and McKelvie (1989).

13 The NEO Five-Factor Inventory is one of the most commonly used methods of assessing personality type. The test measures sixty traits from which five factor scores are calculated. For a discussion of the NEO and other personality tests, see Briggs (1992).

${ }^{14}$ The tests, the questionnaire, and the instructions to first-round dictators are available upon request. We also omit the instructions given to in-room experimenters, those for counters, and the general experimental script that describes the entire set of experiments and which was used in training all the staff participating 
In a departure from more basic dictator games, roughly $80 \%$ of first-round dictators were provided with information about either the gender or the place of origin of their potential recipient. The impact of this information is a matter for analysis elsewhere. ${ }^{16}$ For purposes of the present paper, it is only important to note that both second-round dictators and first-round subjects in the "no information" experimental treatment, whom we refer to as Unconditional Senders, had no knowledge about the identities of their recipients, and no knowledge of these differences in information among first-round senders. Unconditional sending is analyzed below as a benchmark for comparison with sending in the two second-round conditions on which this paper focuses. Amounts sent by dictators in all first-round informational treatments enter into our analysis as amounts received by second-round senders.

Apart from the aforementioned informational variation, dictators in the secondround game were treated in the same manner as those in the first round. The main difference was that before they were asked to determine how much of a $\$ 10$ allotment to keep and how much, if any, to give to an anonymous recipient, each second-round dictator was first given an envelope containing the funds (if any) sent by a dictator in the first-round game. Second-round dictators were told that this money had been sent by a

\footnotetext{
in the experiments. Note that the two parts of the experiment were run coterminously, because first-round dictators became recipients of second-round dictators. Each subject was a dictator only once, a recipient only once. The experiments were run in two batches, one at $10 \mathrm{AM}$ and the other at $1 \mathrm{PM}$, in order to economize on space and staff.

${ }^{15}$ The basic set-up of the first round and accompanying questionnaires was the same as that of experiments run by Ben-Ner, John Dickhaut, Puranjaya Singh, and Dan Magan with 83 subjects at Hamline University in St. Paul, Minnesota, in March and April, 1997 (see Singh, 1997). The instructions for the Hamline experiments were tested extensively with University of Minnesota undergraduates (in Industrial Relations Center classes) to ensure that they were properly understood, particularly with regard to the fact that the dictator has no obligation to send money to the person with whom they are paired. These tests indicated that there was overwhelming comprehension of the instructions.

${ }^{16}$ See Ben-Ner et al., 2001.
} 
participant in another room who had been allowed to send any or none of $\$ 10$ to them under anonymous conditions. Second-round dictators were then given the $\$ 10$ that they themselves were to keep or divide with an anonymous person in another room.

Second-round dictators were divided into two treatment groups. Approximately half of the second-round dictators were told that the person to whom they could give some or no part of their $\$ 10$ was the same individual who gave them some or no money in the envelope that they just received. The other half were told that their recipient had been a sender of one of the envelopes that were distributed to other recipients in their room, but was not the sender of the envelope that he or she personally received. In line with the discussion in section 1, we refer to the two treatments as Specific Reciprocity and Generalized Reciprocity, respectively. Both first- and second-round dictators were told that they would be dividing $\$ 10$ only one time, and that this would be the only decision they would be asked to make during the experiment. Although second-round dictators had the possibility of "reciprocating" the generosity (if any) of first-round dictators, first-round dictators had been given no hint that this might happen, and secondround dictators knew that any reciprocity toward their recipients could not be sustained through later actions. ${ }^{17}$

\section{Experimental Results and Analysis}

\footnotetext{
${ }^{17}$ One might ask why second-round dictators should believe that another round of sending would not follow, in view of the fact that first-round dictators had not been informed about the second round. In answer to this question, we should make clear that second-round senders were informed of their two roles more or less simultaneously, and therefore, they did not view themselves as having first participated in a one-shot procedure as recipients, and as then having received a surprise announcement that a second round would occur in which they would be senders. In other words, the procedure that would not have led second-round senders to believe that the experimenters had a history of adding unannounced stages to the experiment. Note also that there was no deception of first-round senders by the experimenters because, although they were not originally informed about the second-round, they were told nothing that was subsequently contradicted.
} 
The 100 subjects participating in the second-round dictator game received envelopes from 100 participants in the first-round game. ${ }^{18}$ The average amount sent by first-round dictators (and thus the average amount received by second-round dictators) was $\$ 2.83$, with a standard deviation of 2.71 . Twenty-nine subjects sent nothing, and an exactly equal number of subjects sent half or more of their $\$ 10$. The presence of substantial positive sending corroborates the findings of other studies. ${ }^{19}$

Panels $a$ and $b$ of Figure 1 graph the distributions of amounts sent in the Generalized Reciprocity and Specific Reciprocity treatments, respectively. As with firstround subjects, the average amount sent by second-round dictators is strictly positive, averaging $\$ 2.48$ (with a standard deviation of $\$ 2.66$ ), with only 30 subjects sending nothing, and with 27 subjects sending half or more of the $\$ 10$ they were permitted to divide. Seventy percent of the subjects sent one dollar or more.

\footnotetext{
${ }^{18}$ Due to a difference in the show-up rates of first-round and second-round subjects, and to differences in the number of subjects completing all required instruments, the full number of first-round dictators - 116 exceeds the number of second-round dictators providing data for analysis. In this paragraph, we ignore the 16 first-round responses not relevant to this analysis except to note that the 100 whose envelopes were received by our second-round senders are a random subset of the 116, whose decisions follow essentially the same distribution.

19 The average amount sent in the Hamline experiment (see note 15 , above) was $\$ 3.13$. In the additional administration of the first-round experiment at Brown, also using incoming freshmen, the average amount sent was \$3.14. In each instance, average amounts sent were similar to those in the single-blind dictator game experiments surveyed by Roth (1995), but more than the amounts sent in the double-blind experiments of Forsythe et al. (1994), Hoffman et al. (1994), Eckel and Grossman (1996a), and Bolton et al. (1998). Among the possible explanations for this difference, we think it relevant to note (a) that whereas most subjects in the other reported experiments were recruited from economics courses, our newly arrived freshman subjects were drawn from a full cross-section of disciplines and few will as yet have studied college-level economics (see Frank, Gilovich, and Regan (1993) on possible effects of majoring in economics), and (b) the $\$ 15$ participation fee which we paid (due to the length of time required to complete the survey and other tests) is higher than in other experiments, and may have predisposed subjects to greater generosity with the money to be divided. The possibility that attaching an identity to the recipient (male, female, etc.) accounts for the difference in sending levels (compare with Eckel and Grossman's (1996a) finding about sending to the Red Cross) lacks support because subjects in the Unconditional Sending treatment sent no less on average than those given information about the gender or place of origin of their recipient.
} 

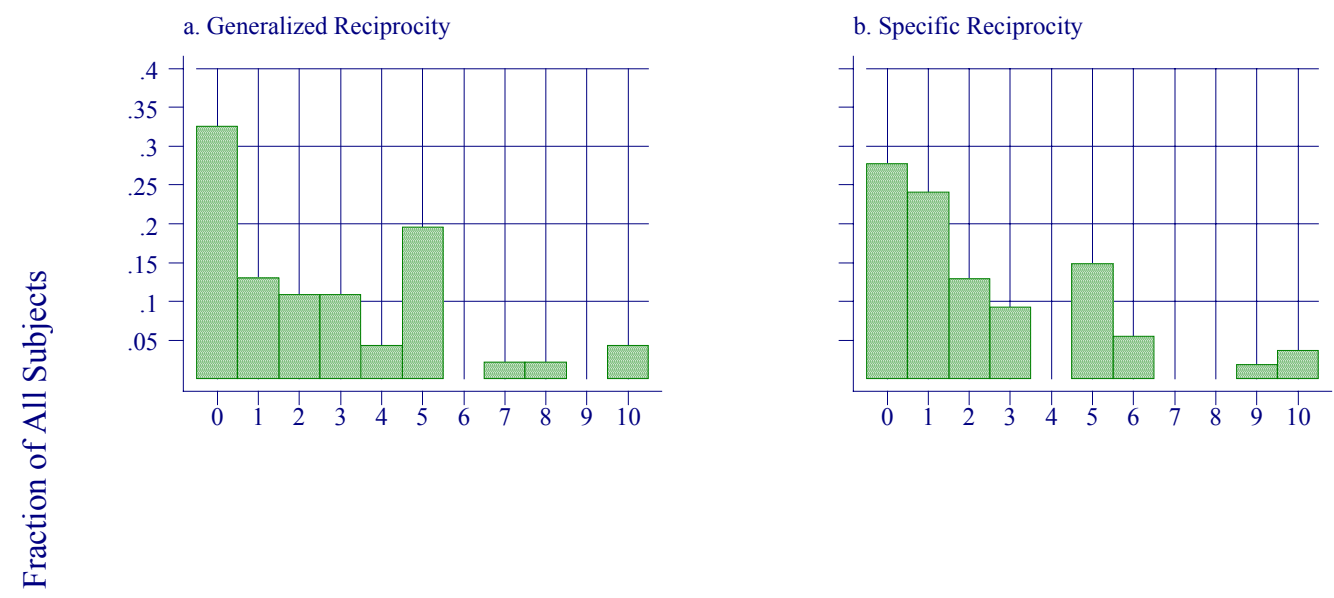

Figure 1. Amount Sent, by Treatments

To begin investigating whether second-round senders manifest reciprocity, consider panels $a$ and $b$ of Figure 2, which plots the frequencies of differences between amounts received and amounts sent in the Generalized Reciprocity and Specific Reciprocity treatments, respectively. The fact that the modal difference is zero in both distributions suggests that amounts received influenced amounts sent. However, the graphs suggest that this influence was greater in the Specific Reciprocity than in the Generalized Reciprocity treatment, since the former distribution is more concentrated in the neighborhood of zero, with narrower tails. 

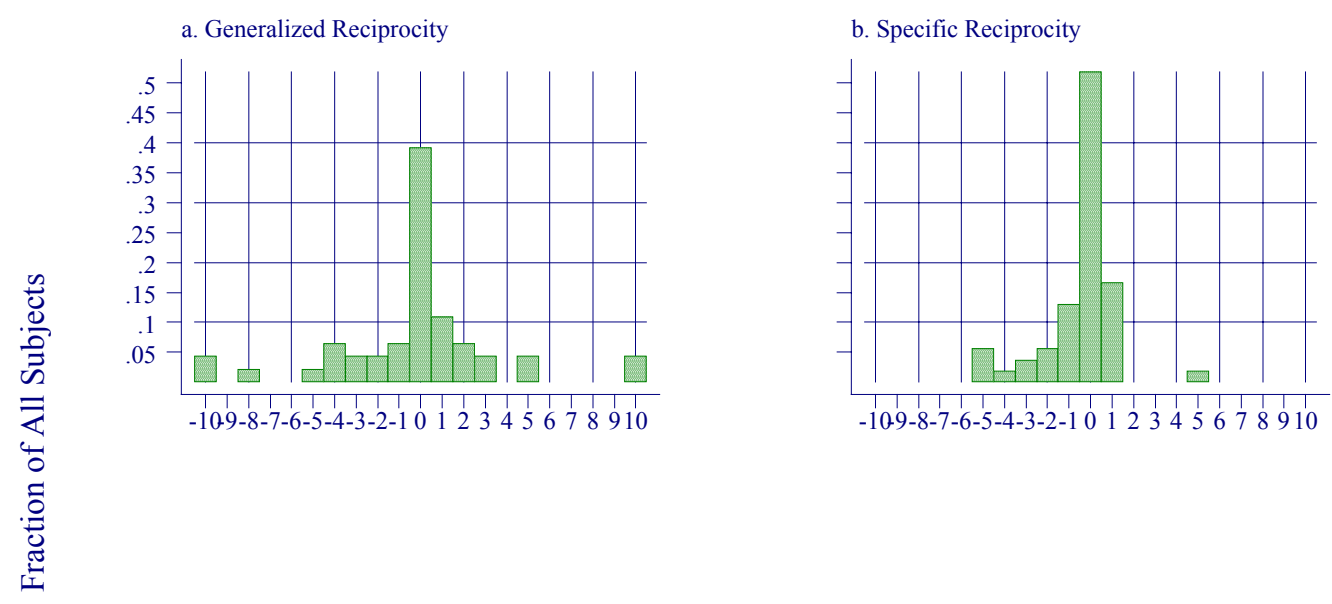

\section{Figure 2 Difference between Amount Sent and Amount Received}

Clearer evidence of the presence of reciprocity, and its differences in the two treatments, can be obtained by bivariate and multivariate regression analysis, with the latter both controlling for other determinants of sending and making it possible to obtain estimates of their impacts. The choices of a second-round dictator i paired with a first-round dictator $\mathrm{j}$ can be analyzed based on two versions of equation (1). For the Specific Reciprocity treatment (SR), we have:

$$
\mathrm{U}_{\mathrm{i}}=\mathrm{f}\left(\mathrm{y}_{\mathrm{i}}, \alpha\left(\mathrm{y}_{\mathrm{j}}, \mathbf{X}_{\mathrm{i}}, \mathbf{X}_{\mathrm{j}}\right), \rho\left(\mathrm{s}_{\mathrm{i}}, \mathrm{s}_{\mathrm{j}}, \mathbf{X}_{\mathrm{i}}, \mathbf{X}_{\mathrm{j}}, \mathrm{SR}\right)\right)
$$

where $y_{i}=y_{i 0}+s_{j}+\left(\$ 10-s_{i}\right)+\$ 15$ and $y_{j}=y_{j 0}+\left(\$ 10-s_{j}\right)+s_{i}+\$ 15 . y_{i 0}$ and $y_{j 0}$ are the pre-experiment incomes or wealth levels of $i$ and $j$, respectively, and as these are not available to us $\left(\mathrm{y}_{\mathrm{j} 0}\right.$ also being unknown to subject $\left.i\right)$ they are ignored for purposes of estimation. Actions $a_{i}$ and $a_{j}$ have been replaced by $s_{i}(=0,1, \ldots, 10)$, the amount sent by $i$ to her receiver, and $\mathrm{s}_{\mathrm{j}}(=0,1, \ldots, 10)$, the amount sent by $j$ to $i$. 
If subject $i$ has strictly self-interested preferences, perhaps due to some elements of the vector $\mathbf{X}_{\mathrm{i}}$, then both $\partial \alpha / \partial \mathrm{s}_{\mathrm{i}}$ and $\partial \rho / \partial \mathrm{s}_{\mathrm{i}}$ equal zero and $i$ maximizes utility by sending nothing (setting $\mathrm{s}_{\mathrm{i}}=0$ ). If $i$ 's preferences include reciprocity, then $\mathrm{s}_{\mathrm{j}}>0$ will cause $\partial \rho / \partial \mathrm{s}_{\mathrm{i}}$ to be positive at $\mathrm{s}_{\mathrm{i}}=0$, which may mean that utility is maximized at a positive value of $\mathrm{si}_{\mathrm{i}}{ }^{20}$ Similarly, $i$ 's preferences may include a concern about $j$ 's income, in which case $\partial \alpha / \partial s_{i}$ is positive at $s_{i}=0$, and the utility-maximizing $s_{i}$ may again be greater than zero. Exactly what value of $\mathrm{s}_{\mathrm{i}}$ maximizes utility depends upon characteristics $\mathbf{X}_{\mathrm{i}}$, including intelligence, personality, moral training, etc., in a manner that we explore empirically in what follows.

The model for the Generalized Reciprocity treatment (GR) is similar, except that there are now three subjects involved, since $k$, the person sending to subject $i$, is not the same individual as $j$, the person to whom $i$ sends. We can write

$$
\mathrm{U}_{\mathrm{i}}=\mathrm{f}\left(\mathrm{y}_{\mathrm{i}}, \alpha\left(\mathrm{y}_{\mathrm{j}}, \mathbf{X}_{\mathrm{i}}, \mathbf{X}_{\mathrm{j}}\right), \rho\left(\mathrm{s}_{\mathrm{i}}, \mathrm{S}_{\mathrm{k}}, \mathbf{X}_{\mathrm{i}}, \mathbf{X}_{\mathrm{j}}, \mathrm{GR}\right)\right)
$$

where $\mathrm{y}_{\mathrm{i}}=\mathrm{y}_{\mathrm{i} 0}+\mathrm{s}_{\mathrm{k}}+\left(\$ 10-\mathrm{s}_{\mathrm{i}}\right)+\$ 15$ and $\mathrm{y}_{\mathrm{j}}=\mathrm{y}_{\mathrm{j} 0}+\left(\$ 10-\mathrm{s}_{\mathrm{j}}\right)+\mathrm{s}_{\mathrm{i}}+\$ 15$. Depending upon $i$ 's characteristics, $\partial \alpha / \partial \mathrm{s}_{\mathrm{i}}$ and $/$ or $\partial \rho / \partial \mathrm{s}_{\mathrm{i}}$ may again be positive at $\mathrm{s}_{\mathrm{i}}=0$, but any influence of $\mathrm{s}_{\mathrm{k}}$ upon $\rho$ will be only general in nature-i.e., subject $i$ would now be emulating but not literally reciprocating any kindness on k's part (since $i$ sends to $j$, not to $k$ ). $i$ does not know $s_{j}$.

To devise an estimating equation from equations (1') and (1''), note that personal characteristics $\mathbf{X}_{\mathrm{i}}, \mathbf{X}_{\mathrm{j}}$, treatment, and amount received, $\mathrm{s}_{\mathrm{j}}$ or $\mathrm{s}_{\mathrm{k}}$, are exogenous to subject $i$,

\footnotetext{
${ }^{20}$ Since subjects were constrained to send whole numbers of dollars, it is possible that 0 remains the utilitymaximizing element in the choice set, because $\partial \rho / \partial \mathrm{s}_{\mathrm{i}}$ could turn negative at a very small positive $\mathrm{s}_{\mathrm{i}}$. At the other end of the choice set, $s_{i}=10$ will be chosen if optimal unconstrained value of $s_{i}$ exceeds 10 .
} 
who can select $s_{i}$ and thereby determine $y_{i}$ and $y_{j}$ to maximize utility $U_{i}$. A reduced form equation for the utility maximizing choice is

$$
\mathrm{s}_{\mathrm{i}}^{*}=\mathrm{g}\left(\mathrm{y}_{\mathrm{i}}, \mathrm{y}_{\mathrm{j}}, \mathbf{X}_{\mathrm{i}}, \mathrm{s}_{\mathrm{o}}, \mathrm{S}\right)
$$

where $\mathrm{S}$ stands for the situation or treatment, and we have either $\mathrm{s}_{\mathrm{o}}=\mathrm{s}_{\mathrm{j}}$ and $\mathrm{S}=\mathrm{SR}$, or else $\mathrm{s}_{\mathrm{o}}=\mathrm{s}_{\mathrm{k}}$ and $\mathrm{S}=\mathrm{GR} . \mathbf{X}_{\mathrm{j}}$ is unknown to the second-round sender, and is thus eliminated from the model, as is the unknown pre-experiment income of sender and receiver.

An unusually rich set of relevant information about our subjects is available from their responses to the NEO, Wonderlic, and survey questionnaires. To preserve degrees of freedom, we select only a few variables for the present analysis. ${ }^{21}$ The included elements of $\mathbf{X}_{\mathrm{i}}$ are: (1) Sex, the standard gender indicator, coded 0 for female and 1 for male, ${ }^{22}$ (2) FewFriends, a dichotomous measure of the number of close friends the subject reports having had while in high school ( 0 for many friends and 1 for few), (3) Visits, a dichotomous variable based on the frequency of visitors to the subject's home while growing up ( 0 for few visits, 1 for many) measuring parental modeling of "sociability," (4) Reltrain, the frequency of attendance of religious school as a child, also dichotomous ( 0 for little or no attendance, 1 for at least weekly attendance) ${ }^{23}$ Agreeable, (6) Neurotic and (7) Open which are, respectively, the personality factors known as "agreeableness," "neuroticism," and "openness" as scored from the NEO five-

\footnotetext{
${ }^{21}$ The principles of selection are (a) inclusion of focal personality and cognitive ability measures, (b) representation of a variety of domains of potentially formative experience, and (c) inclusion of experience variables that were correlated with the dependent variable in preliminary testing.

22 "Which is the fair sex?" is a question studied by Eckel and Grossman (1996b, 1997), Andreoni and Vesterlund (2001), and Ben-Ner, Kong, and Putterman (2001).
} 
factor inventory, ${ }^{24}$ and (8) Cognition, the subject's score on the Wunderlic test, which we use as a measure of cognitive ability. ${ }^{25}$ Table 1 summarizes the variable set, while Table 2 provides descriptive statistics separately for the two second-round treatments (GR and SR) and for the Unconditional (UC) treatment in the first round. ${ }^{26}$

We estimate equation (2) in several variants. Model I excludes all explanatory variables but the amount received, $\mathrm{s}_{0}$. Model II excludes $\mathrm{s}_{0}$ but includes the remaining explanatory variables (Sex, Visits, the personality variables, etc.). Model III includes both $\mathrm{s}_{0}$ and the remaining explanatory variables. A final variant, Model IV, allows for interactions between $\mathrm{s}_{0}$ and the other explanatory variables. There are several estimation methods that can be employed in this situation; the restricted range and discreteness of the dependent variable calls for a method such as ordered logit, the grouping of the data as shown in Figure 1 suggests the possibility of using Tobit estimation, and the possible two-step decision process of subjects - to give or not to give, and then how much to give - may be dealt with a Heckman sample bias correction method. We have employed these

\footnotetext{
${ }^{23}$ The inculcation of moral taste change by religion or other institutions is discussed by Guttman, Nitzan, and Spiegel (1992).

${ }^{24}$ Some personality scholars hypothesize that both personality traits and propensities towards altruism and reciprocity may be partly genetically determined and may vary among individuals in a linked manner. Links between personality factors as measured by the NEO, and altruism and reciprocity, are discussed by Ashton et al. (1998). A popular summary of research on the genetic basis of personality is given by Hamer and Copeland (1998). We tested all five of the NEO's "big five" personality factors and retained the three that were most often statistically significant.

${ }^{25}$ The role of confusion in experimental outcomes is widely discussed, for example by Andreoni (1995). Camerer and Hogart (1999) suggest that "cognitive capital" may substitute for the effort induced by higher payoffs in economics experiments. In her comment on their paper, Eckel (1999) presents evidence that intellectual ability, as measured by student subjects' grade point averages, is associated with the sort of improved performance "that increased incentives normally produce."

${ }^{26}$ Average sending in the UC column does not match average amounts received in the GR and SR columns because the samples involved overlap but are not identical (the UC column excludes first-round Minnesota senders in the treatments including gender and place information but includes senders in the UC treatment at Brown).
} 
and additional methods, and the differences in results are not substantial. Here we present

OLS and ordered logit estimates, which are qualitatively similar. Because OLS gives

convenience of interpretation of findings, we discuss mainly the OLS results.

\section{Table 1: Variable Definitions}

Variable

Definition

\section{Dependent variable}

Send

Dollar amount sent by second-round dictators $(\$ 0, \$ 1, \$ 2, \ldots, \$ 10)$

\section{$\underline{\text { Independent variables }}$}

Received

Sex

FewFriends

Visits

Reltrain

Agreeable

Neurotic

Open

Cognition

RecSex

RecFewFriends

RecVisits

RecReltrain

RecAgreeable

RecNeurotic

RecOpen

RecCognition
Dollar amount received by second-round dictators $(\$ 0, \$ 1, \$ 2, \ldots, \$ 10)$

Gender dummy, 1 if the dictator is male, 0 if female

Friendship dummy, 1 if the dictator had 4 or fewer close friends while in high school, 0 otherwise

Sociability dummy, 1 if the dictator had family members or friends visit a few times a week or more often while growing up, 0 otherwise

Religious training dummy, 1 if the dictator attend Sunday school or other religious training once a week or more often while growing up, 0 otherwise Raw score the dictator earned on NEO Agreeableness scale

Raw score the dictator earned on NEO Neuroticism scale Raw score the dictator earned on NEO Openness scale Raw score the dictator earned on Wunderlic Personnel Test on problemsolving ability

Product of "Received" and "Sex"

Product of "Received" and "FewFriends"

Product of "Received" and "Visits"

Product of "Received" and "Reltrain"

Product of "Received" and "Agreeable"

Product of "Received" and "Neurotic"

Product of "Received" and "Open"

Product of "Received" and "Cognition" 
Table 2: Descriptive Statistics by Experimental Treatment

\begin{tabular}{|c|c|c|c|}
\hline & $\begin{array}{c}\text { Generalized } \\
\text { Reciprocity } \\
\text { (GR) } \\
\end{array}$ & $\begin{array}{c}\text { Specific } \\
\text { Reciprocity } \\
\text { (SR) } \\
\end{array}$ & $\begin{array}{c}\text { First-Round } \\
\text { Sending } \\
\text { (UC) } \\
\end{array}$ \\
\hline Send & $\begin{array}{c}\mathbf{2 . 5 8 7} \\
(2.721) \\
{[0,10]}\end{array}$ & $\begin{array}{c}2.389 \\
(2.631) \\
{[0,10]}\end{array}$ & $\begin{array}{c}\mathbf{3 . 3 7 8} \\
(2.103) \\
{[0,6]}\end{array}$ \\
\hline Received & $\begin{array}{c}\mathbf{2 . 8 2 6} \\
(2.969) \\
{[0,10]}\end{array}$ & $\begin{array}{c}\mathbf{2 . 8 3 3} \\
(2.493) \\
{[0,10]}\end{array}$ & n.a. \\
\hline Sex & $\begin{array}{l}.370 \\
(.488) \\
{[0,1]} \\
\end{array}$ & $\begin{array}{l}.556 * \\
(.502) \\
{[0,1]} \\
\end{array}$ & $\begin{array}{l}.400 \\
(.495) \\
{[0,1]} \\
\end{array}$ \\
\hline Few Friends & $\begin{array}{l}. \mathbf{3 0 4} \\
(.465) \\
{[0,1]}\end{array}$ & $\begin{array}{l}.451 \\
(.503) \\
{[0,1]}\end{array}$ & $\begin{array}{c}.386 \\
(.493) \\
{[0,1]}\end{array}$ \\
\hline Visits & $\begin{array}{l}.674 \\
(.474) \\
{[0,1]}\end{array}$ & $\begin{array}{l}\mathbf{. 5 6 6} \\
(.500) \\
{[0,1]}\end{array}$ & $\begin{array}{l}.467 * * \\
(.505) \\
{[0,1]}\end{array}$ \\
\hline Reltrain & $\begin{array}{l}. \mathbf{7 8 3} \\
(.417) \\
{[0,1]} \\
\end{array}$ & $\begin{array}{c}\mathbf{6 9 2} \\
(.466) \\
{[0,1]} \\
\end{array}$ & $\begin{array}{l}\mathbf{. 6 8 9} \\
(.468) \\
{[0,1]} \\
\end{array}$ \\
\hline Agreeable & $\begin{array}{c}\mathbf{3 1 . 2 8 3} \\
(6.497) \\
{[15,45]}\end{array}$ & $\begin{array}{c}\mathbf{3 0 . 0 7 4} \\
(6.785) \\
{[15,43]}\end{array}$ & $\begin{array}{c}\text { 33.844** } \\
(5.253) \\
{[19,45]}\end{array}$ \\
\hline Neurotic & $\begin{array}{c}\mathbf{2 1 . 3 0 4} \\
(8.192) \\
{[5,41]}\end{array}$ & $\begin{array}{c}21.796 \\
(7.696) \\
{[7,44]}\end{array}$ & $\begin{array}{c}\mathbf{2 1 . 9 1 1} \\
(8.681) \\
{[8,41]}\end{array}$ \\
\hline Open & $\begin{array}{l}\mathbf{3 0 . 5 2 2} \\
(6.538) \\
{[17,43]} \\
\end{array}$ & $\begin{array}{c}\mathbf{2 9 . 7 4 1} \\
(7.354) \\
{[17,46]} \\
\end{array}$ & $\begin{array}{c}\text { 32.711* } \\
(5.747) \\
{[19,42]}\end{array}$ \\
\hline Cognition & $\begin{array}{c}\mathbf{2 8 . 4 7 8} \\
(5.973) \\
{[12,44]}\end{array}$ & $\begin{array}{c}\mathbf{2 8 . 0 0 0} \\
(5.270) \\
{[13,39]}\end{array}$ & $\begin{array}{c}\mathbf{2 9 . 8 6 7} \\
(5.362) \\
{[21,40]}\end{array}$ \\
\hline Number of obs. & 46 & 54 & 45 \\
\hline
\end{tabular}

Note: Two-sample mean and proportion tests are indicated in SR and UC columns, with GR as the comparison baseline. Significance levels are marked with * for $p \leq 0.10$, and $* *$ for $p \leq 0.05$. Standard deviations are in parentheses, and data ranges in brackets. For the send and received variables which are not normally distributed, we have also performed the Kolmogorov-Smirnov test. The test indicates the absence of statistically significant differences between the GR and SR conditions. The amount sent under UC is significantly larger than in either GR or SR at the 0.05 level. 
Each version of the equation was estimated three times: for the pooled sample of second-round senders, for Generalized Reciprocity senders only, and for Specific Reciprocity senders only. Chow tests reject the hypothesis that the same model fits senders in both treatments with $\mathrm{p}$ values .0001 for Model I, .030 for model III and .001 for Model IV, so only the results for the groups separated by treatment are shown. ${ }^{27}$ Since it excludes $\mathrm{s}_{0}$, Model II can be estimated also for first-round senders, and the results are of interest for purposes of comparison. ${ }^{28}$ Table 3 presents the OLS and Table 4 the ordered logit estimates.

Both estimates of Models I and III suggest that there was statistically significant and economically substantial reciprocation of amounts received by senders in the Specific Reciprocity (SR) but not those in the Generalized Reciprocity (GR) treatment. The OLS estimate of Model I suggests that SR senders raised the amount they sent by 83 cents for each additional dollar they received, while after accounting for the effects of other determinants of sending, the OLS estimate of Model III suggests that sending rose 70 cents for each additional dollar received. The effect of amounts received on sending is small and statistically insignificant for senders in the GR treatment, according to the two models. The explanatory power of the amount received is so strong in the SR treatment, and lacking in the GR, that the R-square measure indicates that $61 \%$ of the variance in sending is explained by $\mathrm{s}_{0}$ alone (Model I), for SR, while only $1 \%$ of the variance of GR sending is explained. Using the other variables only, Model II explains only half as much

\footnotetext{
${ }^{27}$ Although the Chow test fails to reject the hypothesis that GR and SR senders are described by the same equation for Model II, separate estimates are shown in the tables for purposes of comparison with the other models.
} 
of the variance of sending for SR subjects as does Model I, while the explained variance rises to a similar $31 \%$ for GR subjects. Finally, comparing the Model I and III estimates suggests that adding the other variables to the model that includes $\mathrm{s}_{0}$ explains an additional $9 \%$ of the variance of SR sending (and 32\% for GR). More than twice as much variance is explained by Model III for SR as for GR subjects.

The pattern of explanatory power for variables other than $\mathrm{s}_{0}$ differs across treatments. For Specific Reciprocity senders, only personality factors (i.e., two of the three personality variables) have individually statistically significant coefficients in models II and III, whereas for Generalized Reciprocity and Unconditional (first-round) senders, other variables appear to have significant effects. GR senders who report having had fewer friends sent more money, according to both models and methods of estimation. (The ordered logit estimates, but not the OLS, suggest that agreeableness also significantly increased sending). In the first-round religious training and openness significantly increased sending. One interpretation is that while life experience appears to influence unconditional sending, once reciprocity is activated, it operates in the fashion of an innate predisposition, with personality traits determining intensity. This interpretation is further supported by Model IV, as discussed below.

The effect of cognitive ability on sending is of considerable interest, since it is plausible to suppose that the sharing of one's endowment in the dictator game results from confusion or lack of cleverness. Using the Wunderlic score as a measure of cognitive ability, the results for both GR and SR treatments fail to support this conjecture.

\footnotetext{
${ }^{28}$ Once again, to eliminate the influence of information about the gender or place of origin of the recipient, which was given to some first-round senders, senders in the UC treatment of the Minnesota and Brown experiments, only, are included in these estimates.
} 
The result for first-round senders is, however, somewhat supportive, as the coefficient on Cognition is negative and significant at the $10 \%$ level in the OLS estimate and at the 5\% level in the ordered logit estimate.

One limitation of the analysis so far is that although we have found evidence of the presence of specific reciprocity based on the significant correlation between amount received and amount sent by Specific Reciprocity dictators, we can say nothing yet about the determinants of reciprocity (as opposed to the determinants of giving per se). To be sure, Model I and especially Model III allow us to determine the overall effect of the amount received on amount sent in a direct fashion, through the coefficient on $\mathrm{s}_{0}{ }^{29}$

However, these models assume that any impacts of the elements of $\mathbf{X}_{\mathrm{i}}$ upon $\mathrm{s}_{\mathrm{i}}$ are independent of the amount received (for instance, working through the altruism function $\alpha$ or through an effect on the concern for fairness only). But perhaps those variables work by altering the reciprocity function $\rho$ so that $\partial \rho / \partial s_{j}$ changes for given values of $s_{j}$. We would like to know how cognition, personality, and our other explanatory variables affect reciprocity, rather than how they affect the amount sent, per se.

\footnotetext{
${ }^{29}$ In an interesting criticism of Berg et al.'s (1995) analysis of trust games, Cox (2000) suggests defining the amount sent out of reciprocity as the difference between total sending and sending in the absence of a reciprocity motive, which he interprets as attributable to other-regarding preferences. Were we to follow this suggestion without reference to individual characteristics, we would find "sending out of reciprocity" to be negative, since our second-round senders on average received slightly more than they sent (compare Received with Send in the GR and SR columns of Table 2). Predicting what the first-round sending would have been had each GR and SR dictator been placed in that treatment instead, by applying the Model II estimates for the UC sender population to the characteristics of individual second-round senders, makes little difference: the approach still implies small or negative amounts sent out of reciprocity. However, our estimates of the coefficients on $\mathrm{s}_{0}$ in Models I and III for SR senders suggest that the conclusion that most or all second-round sending is unrelated to reciprocity is untenable; on the contrary, the highly significant coefficients on amount received imply that most sending was directly associated with amounts received (the Model I [III] SR estimate of the coefficient, .827 [.703], implies average sending of 2.343 [1.992] due to reciprocity, out of actual total sending of 2.389). Even our lowest estimate of $\partial \mathrm{s}_{\mathrm{i}} / \partial \mathrm{s}_{\mathrm{j}}$, from Model IV (see below), suggests that about half of sending is attributable to reciprocity. One reason second-round sending is not larger is that reciprocity and other-regarding preferences may not be additive: if the amount deemed
} 
We explore this matter with the help of Model IV, which includes not only $\mathrm{s}_{0}$ and the $\mathbf{X}_{\mathrm{i}}$ vector, but also their interaction terms. This model clearly performs better (in terms of $\mathrm{R}^{2}$ and $\mathrm{F}$ tests for the inclusion of interaction terms) for Generalized Reciprocity subjects but only marginally so for Specific Reciprocity subjects. ${ }^{30}$ The estimates for senders in the SR treatment further strengthen the conclusion that sending was mainly a function of amount received, determined by a basic predisposition that may vary with personality but shows no sign of varying based on life experiences. The marginal effect of the amount received on the amount sent, computed at the means of all variables, is $0.526 .^{31}$ This is lower than the effect estimated in Models I and III ( 0.827 and 0.703 , respectively), but still substantial. ${ }^{32}$ The performance of the interactions between amount received and the personality factors (especially in the ordered logit but also in the OLS estimate) suggests remarkable predictive power; the marginal effects in this model are similar to those estimated in Model III. Thus the more "agreeable," the more "neurotic,"

appropriate for reciprocity reasons equals or exceeds what would have been sent out of altruism, the altruistic motivation may well be satisfied without additional sending.

${ }^{30}$ In Table 3, test statistics for inclusion of the interaction terms (that is, tests of Model IV against Model III with a null hypothesis that the coefficients of all interaction terms are zeros) are $F(8,28)=3.72$, which has $\mathrm{p}$ value .0045 , for $\mathrm{GR}$, and $\mathrm{F}(8,32)=1.96$, with $\mathrm{p}$ value .0848 , for $\mathrm{SR}$. In the ordered logistic model of Table 4, the likelihood ratio test suggests rejection of Model III in favor of Model IV at the 0.001 level for GR and at the 0.025 level for SR.

${ }^{31}$ The effect of individual variables in Model IV is not directly indicated by the estimated parameters due to the interaction effects. Instead, the effect of a variable can be calculated as the derivative of 'Send' with respect to that variable. The effect of 'Received' on 'Send' is calculated as the estimate on 'received' plus the sum of the products of the estimates on the interacted variables times the variables (estimate on RecSex times Sex plus estimate on RecFewFriends times FewFriends, etc.). A similar calculation was performed to obtain the effects of other variables; the effect of 'sex' is thus the estimate on 'sex' plus the estimate or RecSex times 'sex.' In calculating the effects for Model IV, using the OLS results in Table 3, we evaluated the variables at their GR and SR subsample means reported in Table 2.

${ }^{32}$ If we include in Model IV only the personality variables and their interactions with the amount received then the computed marginal effect of the amount received is 0.740 , similar to that obtained in Models III and I. 
Table 3 Determinants of Sending: OLS Model

\begin{tabular}{|c|c|c|c|c|c|c|c|c|c|}
\hline \multirow{2}{*}{$\begin{array}{r}\text { Model } \\
\text { Variable }\end{array}$} & \multicolumn{2}{|c|}{$\begin{array}{c}\mathbf{I} \\
\mathrm{S}=\mathrm{a}+\mathrm{b} \cdot \mathrm{r}\end{array}$} & \multicolumn{3}{|c|}{$\begin{array}{c}\text { II } \\
\mathrm{S}=\mathrm{a}+\mathbf{X} \boldsymbol{\beta}\end{array}$} & \multicolumn{2}{|c|}{$\begin{array}{c}\text { III } \\
S=a+b \cdot r+X \beta\end{array}$} & \multicolumn{2}{|c|}{$\begin{array}{c}\mathbf{I V} \\
\mathrm{S}=\mathrm{a}+\mathrm{b} \cdot \mathrm{r}+\mathbf{X} \boldsymbol{\beta}+\mathbf{Z} \gamma\end{array}$} \\
\hline & GR & SR & GR & SR & $\mathbf{U C}$ & GR & SR & GR & SR \\
\hline Received & $\begin{array}{l}. \mathbf{1 0 3} \\
(.137)\end{array}$ & $\begin{array}{c}.827 * * * * \\
(.091)\end{array}$ & & & & $\begin{array}{l}.133 \\
(.132)\end{array}$ & $\begin{array}{l}.703 * * * \\
(.098)\end{array}$ & $\begin{array}{l}\text { 2.997* } \\
(1.521)\end{array}$ & $\begin{array}{l}-\mathbf{3 . 2 2 0} * * \\
(1.526)\end{array}$ \\
\hline Sex & & & $\begin{array}{l}-. .302 \\
(.818)\end{array}$ & $\begin{array}{l}.288 \\
(.798)\end{array}$ & $\begin{array}{c}.683 \\
(.663)\end{array}$ & $\begin{array}{l}-.374 \\
(.821)\end{array}$ & $\begin{array}{l}.293 \\
(.533)\end{array}$ & $\begin{array}{l}1.992 * \\
(1.045)\end{array}$ & $\begin{array}{l}.107 \\
(.926)\end{array}$ \\
\hline FewFriends & & & $\begin{array}{l}\mathbf{2 . 2 8 9} * * \\
(.879)\end{array}$ & $\begin{array}{l}.911 \\
(.715)\end{array}$ & $\begin{array}{c}.225 \\
(.733)\end{array}$ & $\begin{array}{c}\mathbf{2 . 4 1 9} * * * \\
(.888)\end{array}$ & $\begin{array}{c}.360 \\
(.484)\end{array}$ & $\begin{array}{c}\mathbf{4 . 0 4 3 * * *} \\
(1.220)\end{array}$ & $\begin{array}{l}-.740 \\
(.745)\end{array}$ \\
\hline Visits & & & $\begin{array}{l}\mathbf{- 1 . 4 0 5} \\
(.889)\end{array}$ & $\begin{array}{l}-.897 \\
(.788)\end{array}$ & $\begin{array}{l}.141 \\
(.695)\end{array}$ & $\begin{array}{l}\mathbf{- 1 . 2 8 0} \\
(.897)\end{array}$ & $\begin{array}{l}-.286 \\
(.533)\end{array}$ & $\begin{array}{l}-.266 \\
(1.302)\end{array}$ & $\begin{array}{l}-.163 \\
(.836)\end{array}$ \\
\hline Reltrain & & & $\begin{array}{l}.466 \\
(.941)\end{array}$ & $\begin{array}{l}\mathbf{1 . 1 8 7} \\
(.801)\end{array}$ & $\begin{array}{c}1.537^{* *} \\
(.680)\end{array}$ & $\begin{array}{l}.517 \\
(.942)\end{array}$ & $\begin{array}{l}.151 \\
(.554)\end{array}$ & $\begin{array}{l}\mathbf{1 . 4 1 1} \\
(1.227)\end{array}$ & $\begin{array}{l}. \mathbf{3 8 2} \\
(.939)\end{array}$ \\
\hline Agreeable & & & $\begin{array}{l}. \mathbf{1 0 5} \\
(.062)\end{array}$ & $\begin{array}{l}. \mathbf{1 6 3} * * \\
(.062)\end{array}$ & $\begin{array}{l}. \mathbf{0 6 4} \\
(.071)\end{array}$ & $\begin{array}{l}. \mathbf{1 0 2} \\
(.062)\end{array}$ & $\begin{array}{c}. \mathbf{1 1 7} * * * \\
(.042)\end{array}$ & $\begin{array}{l}. \mathbf{0 7 5} \\
(.086)\end{array}$ & $\begin{array}{l}-.046 \\
(.065)\end{array}$ \\
\hline Neurotic & & & $\begin{array}{l}.004 \\
(.049)\end{array}$ & $\begin{array}{l}.113 * * \\
(.054)\end{array}$ & $\begin{array}{l}.017 \\
(.040)\end{array}$ & $\begin{array}{l}-.002 \\
(.049)\end{array}$ & $\begin{array}{l}. \mathbf{0 8 5} * * \\
(.036)\end{array}$ & $\begin{array}{l}-.044 \\
(.087)\end{array}$ & $\begin{array}{l}-.079 \\
(.071)\end{array}$ \\
\hline Open & & & $\begin{array}{c}.054 \\
(.060)\end{array}$ & $\begin{array}{l}.060 \\
(.048)\end{array}$ & $\begin{array}{l}.123 * * \\
(.056)\end{array}$ & $\begin{array}{c}. \mathbf{0 4 6} \\
(.060)\end{array}$ & $\begin{array}{c}.035 \\
(.032)\end{array}$ & $\begin{array}{c}. \mathbf{0 8 8} \\
(.069)\end{array}$ & $\begin{array}{c}-.051 \\
(.051)\end{array}$ \\
\hline Cognition & & & $\begin{array}{c}.018 \\
(.067)\end{array}$ & $\begin{array}{l}.014 \\
(.071)\end{array}$ & $\begin{array}{r}-.109 * \\
(.063)\end{array}$ & $\begin{array}{c}. \mathbf{0 2 7} \\
(.068)\end{array}$ & $\begin{array}{l}-.011 \\
(.048)\end{array}$ & $\begin{array}{l}. \mathbf{0 2 2} \\
(.074)\end{array}$ & $\begin{array}{l}-. .020 \\
(.071)\end{array}$ \\
\hline RecSex & & & & & & & & $\begin{array}{c}-\mathbf{1 . 2 7 7} * * * \\
(.299)\end{array}$ & $\begin{array}{c}.066 \\
(.264)\end{array}$ \\
\hline RecFewFriends & & & & & & & & $\begin{array}{c}-.831 * * \\
(.372)\end{array}$ & $\begin{array}{c}.364 \\
(.220)\end{array}$ \\
\hline RecVisits & & & & & & & & $\begin{array}{l}. \mathbf{1 6 6} \\
(.301)\end{array}$ & $\begin{array}{l}\mathbf{- . 0 5 2} \\
(.261)\end{array}$ \\
\hline RecReltrain & & & & & & & & $\begin{array}{c}-.750 * * \\
(.357)\end{array}$ & $\begin{array}{l}.008 \\
(.313)\end{array}$ \\
\hline RecAgreable & & & & & & & & $\begin{array}{l}-.037 \\
(.028)\end{array}$ & $\begin{array}{c}. \mathbf{0 5 7} * * * \\
(.020)\end{array}$ \\
\hline RecNeurotic & & & & & & & & $\begin{array}{l}-.011 \\
(.023)\end{array}$ & $\begin{array}{l}.042 * * \\
(.020)\end{array}$ \\
\hline RecOpen & & & & & & & & $\begin{array}{l}-.034^{*} \\
(.019)\end{array}$ & $\begin{array}{l}. \mathbf{0 2 5} \\
(.016)\end{array}$ \\
\hline RecCognitio & & & & & & & & $\begin{array}{c}.033 \\
(.021)\end{array}$ & $\begin{array}{l}.007 \\
(.023)\end{array}$ \\
\hline Constant & $\begin{array}{c}2.297 * * * \\
(.560)\end{array}$ & $\begin{array}{c}.046 \\
(.342)\end{array}$ & $\begin{array}{l}-\mathbf{2 . 9 3 7} \\
(3.512)\end{array}$ & $\begin{array}{c}-8.246 * * \\
(3.800)\end{array}$ & $\begin{array}{l}-\mathbf{- 1 . 4 2 1} \\
(3.131)\end{array}$ & $\begin{array}{l}\mathbf{- 3 . 2 7 5} \\
(3.527)\end{array}$ & $\begin{array}{c}-\mathbf{6 . 0 5 3} * * \\
(2.557)\end{array}$ & $\begin{array}{l}\mathbf{- 5 . 6 9 4} \\
(4.230)\end{array}$ & $\begin{array}{c}\mathbf{5 . 6 8 6} \\
(4.940)\end{array}$ \\
\hline$\overline{\mathrm{N}}$ & 46 & 54 & 46 & 50 & 44 & 46 & 50 & 46 & 50 \\
\hline Prob. $>\mathrm{F}$ & .459 & .000 & .062 & .036 & .116 & .072 & .000 & .002 & .000 \\
\hline $\mathrm{R}^{2}$ & .013 & .614 & .311 & .314 & .288 & .330 & .701 & .675 & .799 \\
\hline Adj. $R^{2}$ & -.010 & .607 & .162 & .180 & .126 & .163 & .634 & .478 & .693 \\
\hline
\end{tabular}

Note: Standard errors of parameter estimates are reported in parentheses. Significance levels are marked with * for $p \leq 0.10, * *$ for $p \leq 0.05, * * *$ for $p \leq 0.01$. 
Table 4 Determinants of Sending Amount: Ordered Logistic Model

\begin{tabular}{|c|c|c|c|c|c|c|c|c|c|}
\hline \multirow{2}{*}{\begin{tabular}{|r|} 
Model \\
Variable
\end{tabular}} & \multicolumn{2}{|c|}{ I } & \multicolumn{3}{|c|}{ II } & \multicolumn{2}{|c|}{ III } & \multicolumn{2}{|c|}{ IV } \\
\hline & GR & SR & GR & SR & $\mathbf{U C}$ & GR & SR & GR & SR \\
\hline Received & $\begin{array}{c}.088 \\
(.102)\end{array}$ & $\begin{array}{c}.901 * * * \\
(.159)\end{array}$ & & & & $\begin{array}{l}.129 \\
(.106)\end{array}$ & $\begin{array}{c}\mathbf{8 2 0} * * * \\
(.166)\end{array}$ & $\begin{array}{l}2.901 * \\
(1.727)\end{array}$ & $\begin{array}{c}-6.283 * * \\
(2.857)\end{array}$ \\
\hline Sex & & & $\begin{array}{l}-.357 \\
(.631)\end{array}$ & $\begin{array}{c}-.019 \\
(.587)\end{array}$ & $\begin{array}{c}.833 \\
(.665)\end{array}$ & $\begin{array}{c}-.513 \\
(.650)\end{array}$ & $\begin{array}{l}.169 \\
(.654)\end{array}$ & $\begin{array}{c}\mathbf{1 . 5 7 6} \\
(1.095)\end{array}$ & $\begin{array}{c}-.166 \\
(1.246)\end{array}$ \\
\hline FewFriends & & & $\begin{array}{c}1.844 * * * \\
(.667)\end{array}$ & $\begin{array}{c}.239 \\
(.563)\end{array}$ & $\begin{array}{l}.169 \\
(.721)\end{array}$ & $\begin{array}{c}1.984 * * * \\
(.670)\end{array}$ & $\begin{array}{c}-.064 \\
(.594)\end{array}$ & $\begin{array}{c}\mathbf{5 . 2 4 9} * * * \\
(1.493)\end{array}$ & $\begin{array}{c}\mathbf{- 1 . 1 5 2} \\
(1.069)\end{array}$ \\
\hline Visits & & & $\begin{array}{l}-.939 \\
(.693)\end{array}$ & $\begin{array}{l}-.750 \\
(.629)\end{array}$ & $\begin{array}{l}-.282 \\
(.666)\end{array}$ & $\begin{array}{l}-.847 \\
(.690)\end{array}$ & $\begin{array}{l}-.219 \\
(.674)\end{array}$ & $\begin{array}{c}\mathbf{- 1 . 0 8 7} \\
(1.225)\end{array}$ & $\begin{array}{c}\mathbf{- 1 . 1 5 7} \\
(1.145)\end{array}$ \\
\hline Reltrain & & & $\begin{array}{c}.373 \\
(.727)\end{array}$ & $\begin{array}{c}.731 \\
(.636)\end{array}$ & $\begin{array}{c}1.846 * * \\
(.732)\end{array}$ & $\begin{array}{c}.415 \\
(.730)\end{array}$ & $\begin{array}{l}\mathbf{- . 0 5 4} \\
(.667)\end{array}$ & $\begin{array}{l}2.717 * \\
(1.654)\end{array}$ & $\begin{array}{c}\mathbf{8 7 5} \\
(1.252)\end{array}$ \\
\hline Agreeable & & & $\begin{array}{l}.102 * * \\
(.049)\end{array}$ & $\begin{array}{c}.138 * * * \\
(.052)\end{array}$ & $\begin{array}{c}.066 \\
(.067)\end{array}$ & $\begin{array}{l}. \mathbf{1 0 5} * * \\
(.049)\end{array}$ & $\begin{array}{l}.144 * * \\
(.057)\end{array}$ & $\begin{array}{l}.227 * * \\
(.102)\end{array}$ & $\begin{array}{l}-.124 \\
(.102)\end{array}$ \\
\hline Neurotic & & & $\begin{array}{c}-.014 \\
(.040)\end{array}$ & $\begin{array}{l}.077 * \\
(.042)\end{array}$ & $\begin{array}{c}.011 \\
(.038)\end{array}$ & $\begin{array}{c}-.017 \\
(.039)\end{array}$ & $\begin{array}{l}.084 \% \\
(.047)\end{array}$ & $\begin{array}{l}-.186 * \\
(.102)\end{array}$ & $\begin{array}{l}-.216 * \\
(.118)\end{array}$ \\
\hline Open & & & $\begin{array}{c}.039 \\
(.049)\end{array}$ & $\begin{array}{l}.062 \% \\
(.037)\end{array}$ & $\begin{array}{c}\mathbf{. 1 5 1} * * \\
(.059)\end{array}$ & $\begin{array}{c}.029 \\
(.049)\end{array}$ & $\begin{array}{c}.056 \\
(.040)\end{array}$ & $\begin{array}{l}. \mathbf{1 3 3} * \\
(.076)\end{array}$ & $\begin{array}{l}-.127 * \\
(.076)\end{array}$ \\
\hline Cognition & & & $\begin{array}{c}.004 \\
(.056)\end{array}$ & $\begin{array}{c}.044 \\
(.053)\end{array}$ & $\begin{array}{c}-.135 * * \\
(.063)\end{array}$ & $\begin{array}{c}.008 \\
(.059)\end{array}$ & $\begin{array}{l}.006 \\
(.057)\end{array}$ & $\begin{array}{c}-.126 \\
(.087)\end{array}$ & $\begin{array}{c}.014 \\
(.096)\end{array}$ \\
\hline RecSex & & & & & & & & $\begin{array}{c}-1.426 * * * \\
(.376)\end{array}$ & $\begin{array}{c}.071 \\
(.365)\end{array}$ \\
\hline RecFewFriends & & & & & & & & $\begin{array}{c}-\mathbf{1 . 0 6 0} * * * \\
(.410)\end{array}$ & $\begin{array}{c}.423 \\
(.379)\end{array}$ \\
\hline RecVisits & & & & & & & & $\begin{array}{c}.318 \\
(.318)\end{array}$ & $\begin{array}{l}.268 \\
(.365)\end{array}$ \\
\hline RecReltrain & & & & & & & & $\begin{array}{c}-1.174 * * \\
(.494)\end{array}$ & $\begin{array}{c}-.154 \\
(.417)\end{array}$ \\
\hline RecAgreable & & & & & & & & $\begin{array}{c}-.072 * * \\
(.034)\end{array}$ & $\begin{array}{c}.106 * * * \\
(.040)\end{array}$ \\
\hline RecNeurotic & & & & & & & & $\begin{array}{c}.024 \\
(.025)\end{array}$ & $\begin{array}{c}.099 * * * \\
(.038)\end{array}$ \\
\hline RecOpen & & & & & & & & $\begin{array}{c}-.048 * * \\
(.021)\end{array}$ & $\begin{array}{c}\mathbf{. 0 5 6} * * \\
(.025)\end{array}$ \\
\hline RecCognitio & & & & & & & & $\begin{array}{c}.080 * * * \\
(.026)\end{array}$ & $\begin{array}{l}-.005 \\
(.033) \\
\end{array}$ \\
\hline $\mathrm{N}$ & 46 & 54 & 46 & 50 & 44 & 46 & 50 & 46 & 50 \\
\hline Prob $>\chi^{2}$ & .381 & .000 & .033 & .021 & .043 & .033 & .000 & .000 & .000 \\
\hline $\begin{array}{l}\text { Log } \\
\text { likelihood }\end{array}$ & -85.721 & -75.956 & -77.737 & -80.753 & -61.669 & -76.989 & -64.854 & -60.364 & -55.483 \\
\hline Pseudo $\mathrm{R}^{2}$ & .005 & .229 & .097 & .100 & .115 & .106 & .277 & .299 & .382 \\
\hline
\end{tabular}

Note: Standard errors of parameter estimates are reported in parentheses. Significance levels are marked with * for $p \leq 0.10, * *$ for $p \leq 0.05, * * *$ for $p \leq 0.01$. 
and the more "open" the subjects are the greater is the amount they send in response to the amount they receive. There is no indication that cognitive ability influences the propensity to reciprocate (the marginal effect of the cognition variable is 0 ). ${ }^{33}$

The estimates for Generalized Reciprocity dictators are quite different. Unlike in Models I and III, there are now indications that amount received did matter to GR sending. While the coefficient on $\mathrm{s}_{0}$ rises to significance at the $10 \%$ level only, that on some of $\mathrm{s}_{0}$ 's interactions is more significant. The marginal effect of the amount received in this model is 0.307 . Unlike SR senders, the "reciprocity" of GR dictators seems to be influenced by gender, number of friends, and religious training. The marginal effect of the friendship variable is 1.695 (as compared to 2.419 in Model III), suggesting again that fewer friends are associated with more giving, although when we consider the interaction term RecFewFriends separately we conclude that having had more friends while in high school makes subjects more likely to reciprocate than otherwise. Religious training has a small negative marginal effect in this model (-0.709, as compared to 0.517 in Model III). The personality variables have tiny marginal effects, on the same order of magnitude as in Model III. The marginal effect of sex is -1.619 , suggesting that in GR men give less than women. Looking separately at the coefficients on the Sex and RecSex terms suggests a more nuanced interpretation, though: men send more than women, holding amount received constant, but women reciprocate more than men, that is send more back for every dollar received.

The findings of Model IV thus suggest that specific reciprocity, unmediated by gender, personality, cognitive ability, and socialization, is a strong instinct or disposition,

\footnotetext{
${ }^{33}$ The remaining variables also have small marginal effects and are similar to those estimated in Model III.
} 
inducing subjects to give back on average 53 cents on every dollar they receive. Factors other than personality have next to no effect on the reciprocity instinct; in particular, cognitive ability does not affect the disposition to reciprocate. General reciprocity emerges here as weaker and perhaps less instinctive, inducing on average the giving of 31 cents to one person for a dollar received from another person. Much of general reciprocity seems to be the effect of gender and socialization variables, with women, and subjects with fewer friends and less religious training "reciprocating" (i.e., being influenced by the giving they see done by others) more strongly.

\section{Conclusion}

Previous experiments have shown a tendency for individuals to behave more generously than is selfishly rational in one-shot anonymous dictator games. Without prior knowledge by first-round dictators, we added a second-round dictator game in which recipients in the first round had an opportunity to become dictators, with about half of them doing so with their own initial dictators as recipients. The results of this experiment suggest that individuals are inclined to reciprocate sending on the part of a specific other individual, even when that individual is and will remain unknown to them, when their identities and actions cannot be linked by the experimenter, when there is no prospect of ongoing exchange, and when the interaction is zero-sum in nature. We find some evidence for a weak tendency to emulate the behavior of a third party (generalized reciprocity) but only in relationship to certain socialization variables. ${ }^{34}$

\footnotetext{
${ }^{34}$ Our result with respect to the Generalized Reciprocity condition differs from Cason and Mui (1998), who find that the amount sent by a third party dictator has a positive effect on the amount sent by another dictator who is informed of it in their "sequential dictator game." The set-up of their experiment differs
} 
While we cannot discern with certainty whether specific reciprocity is exhibited in the experiment because of a genetic predisposition as opposed to cultural conditioning, the fact that specific reciprocity appears modified only by personality traits, which may have a large genetic component, is suggestive of an innate disposition to reciprocate. Our results also suggest that clearly environmental factors, such as religious training, influence the propensity to share and to be influenced by the sharing of others more than they do the propensity to reciprocate in a specific sense. ${ }^{35}$

Our strongest finding is the core fact that our subjects exhibit reciprocity in a oneshot, zero-sum environment. But other results are also of interest. Gender affects sending only in our generalized reciprocity treatment, where males send more, independent of reciprocity, but females tend to reciprocate more. Subjects with greater cognitive ability give less in our first-round dictator game (unconditional sending), but cognition does not affect reciprocity. Socialization can matter, as religious training has some influence on both sending per se and on generalized reciprocity. Personality factors are good predictors of sending behavior in a number of our tests. These results suggest that great care is needed in assessing the effects of gender, that "social-minded behaviors" are not a special preserve of the less clever, and that measurable personality traits may explain a

from ours in a number of particulars, including the fact that their counterparts to our second-round senders are not themselves recipients and thus not the beneficiaries of the decisions that appear to influence their own.

\footnotetext{
${ }^{35}$ We should emphasize that this sorting of effects into the genetic and the environmental is strictly provisional. As one of the referees noted, a subject pool of American college students shares many elements of socialization in common. The recent work of Heinrich et al. (2001) suggests that experimental results replicated in the universities of cities in the U.S., Europe and Japan may seem universal only because more diverse societies had not yet been sampled.
} 
significant part of the variation in individual behavior in the economics laboratory that remains typically unexplained by economists. 


\section{References}

Aaron, Henry. 1994. "Public Policy, Values, and Consciousness," Journal of Economic Perspectives 8: 3-21.

Akerlof, George. 1982. "Labor Contracts as Partial Gift Exchange," Quarterly Journal of Economics 97: 543-69.

Alexander, Richard, 1987, The Biology of Moral Systems. New York: Aldine de Gruyter.

Andreoni, James. 1995. "Cooperation in Public-Goods Experiments: Kindness or Confusion," American Economic Review 85: 891- 904.

and Lisa Vesterlund. 2001. "Which is the Fair Sex? Gender Differences in Altruism," Quarterly Journal of Economics 116 (1): 293-312.

Ashton, Michael, Sampo Paunonen, Edward Helmes, and Douglas Jackson. 1998. "Kin Altruism, Reciprocal Altruism, and the Big Five Personality Factors," Evolution and Human Behavior 9: 243-55.

Ben-Ner, Avner and Putterman, Louis. 1998. "Values and Institutions in Economic Analysis," in Ben-Ner and Putterman (eds.) Economics, Values, and Organization. New York: Cambridge University Press.

Ben-Ner, Avner and Putterman, Louis. 2000. "On Some Implications of Evolutionary Psychology for the Study of Preferences and Institutions," Journal of Economic Behavior and Organization 43:91-99.

Ben-Ner, Avner, Fanmin Kong, and Louis Putterman. 2001. "Share and Share Alike? Intelligence, Socialization, Personality, and Gender-Pairing as Determinants of Giving," unpublished paper, University of Minnesota and Brown University.

Berg, Joyce, John Dickhaut, and Kevin McCabe. 1995. "Trust, Reciprocity, and Social History," Games and Economic Behavior 10: 122-42.

Bolton, Gary and Axel Ockenfels. 2000. "ERC - A Theory of Equity, Reciprocity and Competition," American Economic Review 90: 166-93.

Bolton, Gary, Elena Katok, and Rami Zwick. 1998. "Dictator Game Giving: Rules of Fairness versus Acts of Kindness," International Journal of Game Theory 27: 269-99.

Briggs, Stephen R. 1992. "Assessing the Five-Factor Model of Personality Description," Journal of Personality 60: 253-93.

Camerer, Colin and Robin Hogarth. 1999. "The Effects of Financial Incentives in Experiments: A Review and Capital-Labor-Production Framework," Journal of Risk and Uncertainty 19: 7-42. 
Camerer, Colin and Richard Thaler. 1995. "Ultimatums, Dictators and Manners," Journal of Economic Perspectives 9: 209-19.

Cason, Timothy and Vai-Lam Mui. 1998. "Social Influence in the Sequential Dictator Game,"'Journal of Mathematical Psychology 42: 248-65.

Cosmides, Leda and John Tooby. 1993. "Cognitive Adaptations for Social Exchange," pp. 63-228 in J. Barkow, L. Cosmides and J. Tooby, eds., The Adapted Mind. New York: Oxford University Press.

Cox, James C. 2000. "Trust and Reciprocity: Implications of Game Triads and Social Contexts," draft, University of Arizona.

Eckel, Catherine. 1999. "Commentary on 'The Effects of Financial Incentives in Experiments: A Review and Capital-Labor-Production Framework'," Journal of Risk and Uncertainty 19: 47-48.

Eckel, Catherine and Philip Grossman. 1996a. "Altruism in Anonymous Dictator Games," Games and Economic Behavior 16: 181-91. . 1996b. "The Relative Price of Fairness: Gender Differences in a Punishment Game," Journal of Economic Behavior and Organization 30: $143-58$.

Evidence from Dictator Experiments," Economic Journal 108: 726-35.

Edgeworth, Francis Y. 1967. Mathematical Psychics: An Essay on the Application of Mathematics to the Moral Sciences. New York: A.M. Kelley.

Falk, Armin and Urs Fischbacher. 1998. "A Theoy of Reciprocity,” Working Paper, University of Zurich.

Fehr, Ernst, and Simon Gächter. 2002. "Altruistic Punishment in Humans," Nature 415: $125-8$. , and Georg Kirchsteiger. 1997. "Reciprocity as a Contract Enforcement Device: Experimental Evidence,” Econometrica 65: 833-60.

Fehr, Ernst and Klaus Schmidt. 2000. "A Theory of Fairness, Competition, and Cooperation," Quarterly Journal of Economics 114: 817-68.

Fershtman, Chaim and Yoram Weiss. 1998. "Why Do We Care What Others Think About Us?" in Ben-Ner and Putterman (eds.) Economics, Values, and Organization. New York: Cambridge University Press. 
Forsythe, Robert, Joel L. Horowitz, N.E. Savin, and Martin Sefton. 1994. "Fairness in Simple Bargaining Experiments," Games and Economic Behavior 6: 347-69.

Frank, Robert. 1987. "If Homo Economicus Could Choose His Own Utility Function, Would He Want One With a Conscience?" American Economic Review 77: 593-604.

. 1988. Passions within Reason: The Strategic Role of the Emotions. New York: W.W. Norton.

, Thomas Gilovich, and Dennis Regan. 1993. "Does Studying Economics Inhibit Cooperation?," Journal of Economic Perspectives 7:159-71.

Gintis, Herbert. 1997. "The Individual in the Economy: The Nature and Origins of Preferences, with Implications for Social Policy (A Proposal to the MacArthur Foundation)," mimeo, University of Massachusetts, Amherst.

Guttman, Joel, Shmuel Nitzan, and Uriel Spiegel. 1992. "Rent Seeking and Social Investment in Taste Change," Economics and Politics 4: 31-42.

Guttman, Joel. 1996. "A Model of Self-Enforcing Agreements Between and Within Generations in Developing Economies,” unpublished paper, Bar-Ilan University.

Hamer, Dean and Peter Copeland. 1998. Living With our Genes: Why they Matter More than you Think. New York: Doubleday.

Hawkins, K., S. Faraone, J. Pepple, and L. Seidman. 1990. "WAIS-R Validation of the Wonderlic Personnel Test as a Brief Intelligence Measure in a Psychiatric Sample," Psychological Assessment 2: 198-201.

Heinrich, Joseph, Samuel Bowles, Robert Boyd, Colin Camerer, Ernst Fehr, Herbert Gintis, and Richard McElreath. 2001. "Cooperation, Reciprocity and Punishment in 15 Small-Scale Societies," American Economic Review 91: 73-8.

Hirshleifer, Jack. 1987. "On the Emotions as Guarantors of Threats and Promises," in John Dupré, The Latest on the Best: Essays on Evolution and Optimality. Cambridge: MIT Press.

Hoffman, Elizabeth, Kevin McCabe, Keith Shachat, and Vernon Smith. 1994. "Preferences, Property Rights, and Anonymity in Bargaining Games," Games and Economic Behavior 7: 346-80. , and Vernon Smith. 1996. "Social Distance and Other-Regarding Behavior in Dictator Games," American Economic Review 86: 653-60. 
. 1998. "Behavioral Foundations

of Reciprocity: Experimental Economics and Evolutionary Psychology," Economic Inquiry 36: 335-52.

Kaplan, Hillard and Kim Hill. 1985. "Food Sharing among Ache Foragers: Tests of Explanatory Hypotheses," Current Anthropology 26: 223-46.

Knight, Frank H. 1922. "The Ethics of Competition," Quarterly Journal of Economics 36: 454-81.

Lindbeck, Assar. 1995. "Hazardous Welfare State Dynamics," American Economic Review (Papers and Proceedings) 85: 9-15.

Lumsden, Charles and Edward O. Wilson. 1983. Promethian Fire: Reflections on the Origin of Mind. Cambridge: Harvard University Press.

McCabe, Kevin, Stephen Rassenti, and Vernon Smith. 1996. "Game Theory and Reciprocity in Some Extensive Form Bargaining Games," Proceedings of the National Academy of Science, November, 13421-28.

McKelvie, S. 1989. "The Wonderlic Personnel Test: Reliability and Validity in an Academic Setting," Psychological Reports, 65: 161-162.

Nowak, Martin and Karl Sigmund, 1998, "Evolution of Indirect Reciprocity by Image Scoring," Nature 373: 573-77.

Roth, A. E. 1995. "Bargaining Experiments," pp. 253-348 in J. Kagel and A. E. Roth, eds., Handbook of Experimental Economics. Princeton: Princeton University Press.

Schelling, Thomas. 1960. The Strategy of Conflict. Cambridge: Harvard University Press.

Sen, Amartya K. 1998. "Foreword," in Ben-Ner and Putterman, eds., Economics, Values and Organization. New York: Cambridge University Press.

Singh, Puranjaya. 1997. "Human Behavior in Dictator Games," Ph.D. Thesis, Industrial Relations Center, University of Minnesota.

Trivers, Robert. 1985. Principles of Social Evolution. Menlo Park,CA:

Benjamin/Cummings Publishing Co.

de Waal, Frans. 1996. Good Natured: The Origins of Right and Wrong in Humans and Other Animals. Cambridge: Harvard University Press.

Wright, Robert. 1994. The Moral Animal: Why We Are the Way We Are: The New Science of Evolutionary Psychology. New York: Vintage Books. 